\title{
Persepsi Masyarakat Terhadap Pemberlakuan Social Distancing Di Masa Pandemi Covid-19 Sebagai Implementasi Modal Sosial
}

\author{
Ade Suherman, Tetep, Asep Supriyatna, Eldi Mulyana, Triani Widyanti, Opah Saripah, Aneu Rostiani, \\ Lilik Purnawati \\ Institut Pendidikan Indonesia \\ Jl. Terusan Pahlawan No.32, RW.01, Sukagalih, Kec. Tarogong Kidul, Kabupaten Garut, Jawa Barat 44151 \\ adesuhermana@gmail.com
}

\begin{abstract}
The purpose of this study is to analyze and explain public perceptions of the implementation of social distancing during the pandemic as the implementation of social capital. This study was motivated by the phenomenon of the outbreak of the Covid-19 pandemic in a number of countries, including Indonesia. This condition not only affects the economic condition of a country, hinders social interaction among the community, and also has an impact on the health condition of every human being. To avoid the wider spread of Covid-19, the government was forced to adopt social distancing and physical distancing policies in the form of staying at home, working from home, studying, and worshiping at home. This research approach is descriptive qualitative. The data of this research is the impact of social distancing for the community in Tarogong Kidul District, Garut Regency. Sources of data come from several communities with a total of 50 respondents. Collecting data in this study using interview techniques, record, and continue to take notes. The results of the research can be concluded that with the implementation of social distancing in the pandemic period, at least the community can implement social capital which includes informal values or norms that are shared among members of an interrelated community group, which is based on the values of beliefs, norms and networks social and they respect each other, the development of social capital is the creation of increa singly independent groups of people who are able to participate more meaningfully. Social capital can solve citizens' problems, especially with regard to strengthening friendship, repairing and maintaining public service facilities because it has advantages and is the most appropriate, even though there are other social capital in the community.
\end{abstract}

Keywords: Community Perception, Social Distancing, Social Capital.

\begin{abstract}
Abstrak- Tujuan penelitian ini untuk menganalisis dan menjelaskan Persepsi masyarakat terhadap pemberlakuan social distancing di masa pandemi sebagai implementasi modal sosial. Kajian ini dilatar belakangi oleh fenomena merebaknya pandemik Covid-19 di sejumlah negara, termasuk pula di Indonesia. Kondisi ini tidak hanya berdampak pada kondisi perokonomian suatu negara, menghambat interaksi sosial di kalangan masyarakat, serta juga memiliki dampak terhadap kondisi kesehatan setiap manusia. Unt uk menghindari penyebaran Covid-19 yang lebih luas, pemerintah terpaksa mengambil kebijakan pembatasan sosial (social distancing) dan pembatasan kontak fisik (physical distancing) berupa tinggal di rumah, bekerja dari rumah, belajar, dan beribadah di rumah. Pendekatan penelitian ini adalah deskriptif kualitatif. Data penelitian ini adalah dampak adanya social distancing bagi masyarakat di Kecamatan Tarogong Kidul Kabupaten Garut. Sumber data berasal dari beberapa masyarakat berjumlah 50 responden. Pengumpulan data pada penelitian ini menggunakan teknik wawancara, rekam, dan dilanjutkan catat. Hasil penelitian dapat disimpulkan bahwa dengan adanya Pemberlakuan Social Distancing Di Masa Pandemi setidaknya masyarakat dapat mengimplementasikan Modal Sosial yang meliputi nilai atau norma-norma informal yang dimiliki bersama diantara para anggota suatu kelompok masyarakat yang saling terkait, yang didasarkan pada nilai kepercayaan, norma, dan jaringan sosial dan mereka saling menghargai, pengembangan modal sosial adalah terciptanya kelompok masyarakat yang semakin mandiri, yang mampu berpartisipasi secara lebih berarti. Modal sosial dapat menyelesaikan permasalah warga terutama berkenaan dengan penguatan tali silaturahim, perbaikan dan pemeliharaan sarana pelayanan publik karena memiliki kelebihan dan paling sesuai, meskipun pada komunitas tersebut terdapat modal sosial lain.
\end{abstract}

Kata Kunci: Persepsi Masyarakat, Social Distancing, Modal Sosial.

\section{PENDAHULUAN}

Dampak pandemik Covid-19 secara global termasuk Indonesia saat ini dihadapkan pada situasi sulit terkait dengan penanganan dampak pandemik covid-19, usaha-uasaha yang dilakukan terkait dengan upaya untuk menekan angka kematian penduduk yang terinfeksi virus covid-19, maupun upaya untuk menangani dampak sosial ekonomi dari penyebaran virus. Kesigapan dan upaya antisipasi yang dilakukan 
pemerintah Indonesia pada masa awal penyebaran virus covid-19 ini seringkali dipertanyakan banyak pihak yang meragukan claim pemerintah bahwa Indonesia adalah negara yang bebas penyebaran virus covid-19 (Sakti \& Pribadi, 2018). Virus Corona atau disebut pula Covid19 (Corona Virus Disease 2019) ditemukan pertama kali di Kota Wuhan, China pada akhir Desember 2019 (Yunus \& Rezki, 2020).

Penyebaran virus corona padaa jangka waktu yang relatif singkat, virus ini dengan sangat cepat telah menyebar ke hampir seluruh negara di dunia, termasuk Indonesia. Sejumlah pengamat mengkategorikan Covid-19 sebagai salah satu jenis virus yang sangat berbaya dan mematikan. Orang yang terinfeksi virus Covid-19 ditandai akan mengalami gejala flu yang disertai demam, pilek, batuk kering, sakit tenggorokan, dan sakit kepala (Yuliana, 2020). WHO mengemukakan pada sejumlah kasus ditemukan pasien yang memiliki imunitas sangat lemah dapat berakibat fatal apabila tidak mendapatkan penanganan medis secara cepat dan tepat yakni dapat mengakibatkan kematian (Yusup, Badriyah, Suyandi, \& Asih, 2020). Melihat begitu berbahayanya dampak yang ditimbulkan oleh Covid-19, hampir setiap negara di dunia termasuk Indonesia mengambil langkahlangkah preventif berupa pembatasan sosial, pengaturan jarak fisik, serta karantina wilayah baik dalam skala penuh maupun terbatas serta mencari vaksin yang tepat sebagi pencegahan.

Kebijakan pemerintah dalam Pembatasan Sosial Distancing atau Pembatasan Skala Besar (PSBB) terpaksa diambil oleh sejumlah negara sebagai pilihan pahit untuk meminimalkan dan menekan jumlah penyebaran Covid-19 yang terus meningkat dari waktu ke waktu. Di saat yang sama, para ahli kesehatan di berbagai negara juga belum menemukan vaksin tepat dan mampu mengobati orang yang terinfeksi virus covid-19. Dengan kata lain, Covid-19 bukan hanya menjadi pandemik, tetapi juga telah menjadi bencana yang sangat mematikan bagi manusia di berbagai negara. Mengacu kepada hasil update terakhir tertanggal 14 Mei 2020 ini, tercatat sudah ada 12 negara di dunia yang mengalami bencana pandemic Covid-19, dengan jumlah terkonfirmasi 4.452.806 kasus, meninggal dunia 298.737 orang, sedangkan pasien yang berhasil sembuh yakni 1.675.928. Sedangkan data terkonfirmasi di Indonesia, berdasar data yang diunggah melalui situs https://covid19.go.id/ telah mempublikasikan data yang cukup mencengangkan, yaitu dinyatakan positif 16.006 kasus, sembuh 3.518 orang, dan meninggal dunia 1.043 orang. Berdasarkan kondisi tesebut seluruh pihak baik pemerintah maupun masyarakat berharap banyak semua kasus tersebut dapat menurun jumlahnya melalui diberlakukannya kebijakan pembatasan sosial (Social Distancing), pembatasan jarak fisik (Physical Distancing).

Modal sosial kemudian dianggap sebagai kerangka teoritis yang bermanfaat dalam paradigma pembangunan inklusif berkelanjutan. Posisi modal sosial menjadi penting untuk disorot mengingat paradigma pembangunan yang diberlakukan tersebut lebih bersifat bottom up ketimbang top down. Modal sosial masuk dalam dimensi sosial dari paradigma pembangunan berkelanjutan yang mencoba mengintegrasikan tiga dimensi: sosial, ekonomi dan lingkungan. Selain itu, posisi modal sosial juga berperan positif dalam dimensi politik karena mendorong partisipasi, aksesibilitas dan kebebasan masyarakat yang juga menjadi prinsip dalam paradigma pembangunan inklusif berkelanjutan.

Beberapa masalah sejak diterapkannya social distancing permasalah warga terutama berkenaan dengan penguatan tali silaturahim, perbaikan dan pemeliharaan sarana pelayanan publik karena memiliki kelebihan dan paling sesuai, meskipun pada komunitas tersebut terdapat modal sosial lain. Ketiga. Jimpitan semula sebagai pengikat tali silaturahim warga kemudian justru menjadi jembatan bagi pengikat tali silaturahim yang terbentuk pada modal sosial lainnya.

Pada saat pandemic covid-19 saat ini, modal sosial dibutuhkan dalam berinterkasi dengan manysarakat. Dengan adanya Pemberlakuan Social Distancing Di Masa Pandemi setidaknya masyarakat dapat mengimplementasikan Modal Sosial yangh meliputi nilai atau norma-norma informal yang dimiliki bersama diantara para anggota suatu kelompok masyarakat yang saling terkait, yang didasarkan pada nilai kepercayaan, norma, dan jaringan sosial dan mereka saling menghargai. Data penelitian ini adalah dampak adanya social distancing bagi masyarakat di Kecamatan Tarogong Kidul Kabupaten Garut. Sumber data berasal dari beberapa masyarakat berjumlah 50 responden.

Dampak dari PSBB berimplikasi pada ekonomi social dan budaya. Pemberlakuan Social Distancing Di Masa Pandemi setidaknya masyarakat dapat mengimplementasikan Modal Sosial yang meliputi nilai atau norma-norma informal yang dimiliki bersama diantara para anggota suatu kelompok masyarakat yang saling terkait, yang didasarkan pada nilai kepercayaan, norma, dan jaringan sosial dan mereka saling menghargai, 
pengembangan modal sosial adalah terciptanya kelompok masyarakat yang semakin mandiri, yang mampu berpartisipasi secara lebih berarti.

\section{KAJIAN PUSTAKA}

\section{Social Distancing}

Berdasarkan PP Nomor 21 Tahun 2020 Pasal 1, dijelaskan bahwa Pembatasan Sosial Berskala Besar merupakan pembatasan kegiatan tertentu dalam suatu wilayah yang diduga terinfeksi Coronavirus Disease 2019 (COVID-19). 1) PSBB itu sendiri merupakan salah satu strategi pemerintah dalam mencegah kemungkinan penyebaran virus corona, yang mana juga telah tertuang di dalam aturan PMK Nomor 9 Tahun 2020 pasal 2 yang telah ditetapkan oleh Menkes pada Jumat, 3 April 2020, bahwa untuk dapat ditetapkan sebagai PSBB, maka suatu wilayah provinsi/kabupaten/kota harus memenuhi dua kriteria.

2) Pertama, yaitu jumlah kasus atau kematian akibat penyakit meningkat dan menyebar secara signifikan secara cepat ke beberapa wilayah. 3) Sementara kriteria kedua adalah bahwa wilayah yang terdapat penyakit juga memiliki kaitan epidemiologis dengan kejadian serupa yang terdapat di wilayah atau negara lain.

Dari kedua kriteria itulah pada nantinya Menkes dapat menentukan apakah wilayah atau daerah tersebut layak untuk diterapkan PSBB atau tidak. Pembatasan tersebut meliputi peliburan sekolah dan tempat kerja, pembatasan kegiatan keagamaan, pembatasan kegiatan di tempat atau fasilitas umum, pembatasan kegiatan sosial budaya, pembatasan moda transportasi, dan pembatasan kegiatan lainnya khusus terkait aspek pertahanan dan keamanan Pembatasan Sosial Berskala Besar (PSBB) dilaksanakan selama masa inkubasi terpanjang dan dapat diperpanjang jika masih terdapat bukti penyebaran. Permenkes itu menjelaskan, sekolah dan tempat kerja diliburkan kecuali kantor atau instansi strategis yang memberikan pelayanan terkait: 1. pertahanan dan keamanan 2 . ketertiban umum 3. kebutuhan pangan 4. bahan bakar minyak dan gas 5 . pelayanan kesehatan 6 . perekonomian 7. keuangan 8. komunikasi 9. industri 10. ekspor dan impor 11. distribusi logistik, dan kebutuhan dasar lainnya. Adapun pada pembatasan kegiatan keagamaan, dilaksanakan dalam bentuk kegiatan keagamaan yang dilakukan di rumah dan dihadiri keluarga terbatas, dengan menjaga jarak setiap orang. Di luar itu, kegiatan keagamaan dilakukan dengan berpedoman pada peraturan perundangundangan, dan fatwa atau pandangan lembaga keagamaan resmi yang diakui oleh pemerintah Untuk pembatasan kegiatan di tempat atau fasilitas umum dilaksanakan dalam bentuk pembatasan jumlah orang dan pengaturan jarak orang. Kegiatan tersebut terkecuali bagi: 1. supermarket, minimarket, pasar, toko atau tempat penjualan obat-obatan dan peralatan medis kebutuhan pangan, barang kebutuhan pokok, barang penting, bahan bakar minyak gas dan energi. 2 . fasilitas pelayanan kesehatan atau fasilitas lain dalam rangka pemenuhan pelayanan kesehatan. 3. tempat atau fasilitas umum untuk pemenuhan kebutuhan dasar penduduk lainnya termasuk kegiatan olahraga. Kemudian pada pembatasan kegiatan sosial dan budaya dilaksanakan dalam bentuk pelarangan kerumunan orang dalam kegiatan sosial dan budaya serta berpedoman pada pandangan lembaga adat resmi yang diakui pemerintah dan peraturan perundangundangan. Pembatasan moda transportasi dikecualikan untuk: 1). moda transpotasi penumpang baik umum atau pribadi dengan memperhatikan jumlah penumpang dan menjaga jarak antar penumpang 2). moda transpotasi barang dengan memperhatikan pemenuhan kebutuhan dasar penduduk. Pembatasan kegiatan lainnya khusus terkait aspek pertahanan dan keamanan dikecualikan untuk kegiatan aspek pertahanan dan keamanan dalam rangka menegakkan kedaulatan negara, dan mempertahankan keutuhan wilayah, dengan tetap memperhatikan pembatasan kerumunan orang serta berpedoman kepada protokol dan peraturan perundang-undangan.

\section{Modal Sosial}

Dalam konteks pembangunan nasional, telah dilakukan banyak kajian yang melihat peran modal sosial dalam menciptakan tata kelola pemerintahan yang baik, di antaranya yaitu dilakukan oleh Haridison (2013) yang melihat peran modal sosial dalam pembangunan. Hasil kajian tersebut merupakan kajian literatur yang melihat konsep modal sosial yang diterapkan dalam beberapa aspek pembangunan: politik, manusia dan ekonomi. Penelitian tersebut menyimpulkan bahwa permasalahan dan penyimpangan yang terjadi di berbagai negara, determinan utamanya adalah kerdilnya modal sosial yang tumbuh di tengah masyarakat. Sama halnya Haridison, Syahra (2003) menyimpulkan bahwa ketika modal sosial diaplikasikan dengan baik maka kontribusi terpenting pengembangan modal sosial adalah terciptanya kelompok masyarakat yang mandiri.

Dalam rangka pemberdayaan kepada masyarakat, maka modal sosial masih sangat digemari 
para akademisi maupun praktisi sebagai kerangka teoritis untuk melahirkan strategi-strategi pemberdayaan. Hasil penelitian Balady (2018) melihat modal sosial dalam pemberdayaan komunitas. Penelitian tersebut menyimpulkan bahwa komunitas masyarakat tertentu memiliki berbagai bentuk modal sosial yang berkontribusi dalam peningkatan kesejahteraan dan kelestarian lingkungan mereka ketika modal sosial tersebut melebur dalam program PLBHK. Lebih jauh, modal sosial di antaranya mampu mengembangkan ekonomi Lembaga Keuangan Mikro (LKM), (Sila, 2010) dan Pedagang Kaki Lima (PKL) (Utomo, 2015).

Modal sosial juga hadir sebagai solusi pengentasan kemiskinan Rumah Tangga Miskin (RTM) (Kamarani, 2012). Lebih dari itu, modal sosial juga berguna bagi pemberdayaan ekonomi perempuan (Puspitasari, 2012) dan pemberdayaan komunitas perempuan majelis taklim (Asrori, 2014). Terakhir, penelitian modal sosial yang berhasil ditemukan ternyata berpengaruh bagi perilaku pelaku Usaha Mikro Kecil Menegah (UMKM) (Thobias et al, 2013). Bukan hanya itu, modal sosial ternyata memiliki peran dalam menciptakan ketahanan ekonomi yang baik bagi ojek pangkalan (Fathy, 2017). Di sisi lain, keterkaitan modal sosial dengan isu lingkungan khususnya masalah persampahan, misalnya dilakukan dalam penelitian Syahli dan Sekarningrum (2017). Hasil penelitian tersebut mendeskripsikan pengelolaan sampah berbasis modal sosial masyarakat. Modal sosial merupakan kekuatan sosial masyarakat dalam mencapai tujuan bersama dalam hal ini menciptakan kawasan bebas sampah Modal sosial sebagai sebuah kerangka teoritis seyogianya dapat diadopsi dalam beragam aspek kehidupan masyarakat. Pemanfaatan modal sosial dalam pembangunan, pemberdayaan masyarakat dan pengelolaan lingkungan merupakan contoh bagaimana sebuah modalitas yang bertumpu pada pendayagunaan relasi sosial diaplikasikan. Dapat dibuktikan berdasarkan hasil kajian-kajian terdahulu bahwa setiap masyarakat (dalam arti luas) memiliki potensi modal sosial yang apabila dikembangkan akan memberikan manfaat bagi kemudahan, baik dalam memperoleh keuntungan ekonomi maupun manfaat sosial. Setidaknya ada tiga tema utama dalam kajian mengenai modal sosial yang akan dijabarkan berikut ini.

\section{METODE PENELITIAN}

Pendekatan penelitian ini adalah deskriptif kualitatif. Menurut Moleong (2005:6), penelitian kualitatif adalah penelitian yang bermaksud untuk memahami fenomena tentang apa yang dialami oleh subjek penelitian misalnya perilaku, persepsi, motivasi, tindakan, dll secara holistic, dan dengan cara deskripsi dalam bentuk kata-kata dan bahasa, pada suatu konteks khusus yang alamiah dan dengan memanfaatkan berbagai metode alamiah

Data penelitian ini adalah dampak adanya social distancing bagi masyarakat di Kecamatan Tarogong Kidul Kabupaten Garut. Sumber data berasal dari beberapa masyarakat berjumlah 50 responden. Pengumpulan data pada penelitian ini menggunakan teknik wawancara, rekam, dan dilanjutkan catat

\section{HASIL DAN PEMBAHASAN}

Berdasarkan wawancara dengan perwakilan masyarakat Kecamatan Tarogong Kidul Kabupaten Garut, bahwa Persepsi masyarakat terhadap penerapan Pemberlakuan Social Distancing Di Masa Pandemi Sebagai Implementasi Modal Sosial, sebagai berikut:

1. Physical Distancing Physical distancing

Mereka beranggapan bahwa dengan penerapan physical distancing dapat mengurangi kemungkinan kontak fisik antara orang yang terinfeksi dan orang lain yang tidak terinfeksi, sehingga dapat meminimalkan terjadinya penularan penyakit, virus, morbiditas, dan akibat buruk lainnya yang dapat berakibat kepada kematian. Physical distancing efektif dilakukan untuk menvegah penularan infeksi virus yang dapat ditularkan melalui kontak fisik yang meliputi kontak seksual, kontak fisik tidak langsung misalnya dengan menyentuh permukaan yang terkontaminasi,atau transmisi melalui udara, atau dapat juga mengenai percikan atau droplet yang berasal dari batuk atau bersin. Dengan adanya batas jarak fisik di masyarakat melalui kebijakan pemerintah sebagai alternatif pencegahan perluasan dampak infeksi virus Covid-19 yang dipilih oleh pemerintah Indonesia khususnya pada masyarakat Tarogong Kidul dapat menimbulkan berkurangnya produktivitas, dan hilangnya manfaat lain yang berkaitan dengan interaksi antar manusia untuk menjaga eksistensi dan keberlangsungan hidup, selain itu kesulitan masyarakat dalam memperoleh alat pelindung diri seperti masker handsanitizer dan alat pelindung diri lainnya sering kali mempersulit masyarakat untuk menjaga kesehatannya. Pada prakteknya masyarakat dapat menerapkan physical distancing dengan melakukan beberapa cara seperti, tidak 
meninggalkan rumah kecuali untuk kondisi yang sangat genting seperti membeli kebutuhan pokok atau berobat, menyapa orang lain dengan melambaikan tangan tidak berjabat tangan, rutin melakukan kegiatan olahraga dirumah minimal 30 menit sehari untuk menjaga daya tahan tubuh, memanfaatkan fasilitas gadget yang tersedia dirumah agar tetap dapat bekerja atau belajar dari rumah.

2. Social Distancing

Persepsi masyarakat terhadap pembatasan sosial (social distancing) dapat menciptakan jarak antara diri sendiri dengan orang lain untuk mencegah penularan penyakit tertentu. Pembatasan kegiatan tertentu penduduk dalam suatu wilayah yang diduga terinfeksi penyakit dan/atau terkontaminasi sedemikian rupa untuk mencegah kemungkinan penyebaran penyakit atau kontaminasi. Mengacu kepada aturan tersebut social distancing bertujuan menekan potensi penyebaran penyakit menular, di mana social distancing bertujuan untuk membatasi kegiatan sosial orang untuk menjauh dari kontak fisik dan keramaian. Dalam penerapan social distancing, seseorang tidak diperkenankan untuk berjabat tangan serta senantiasa memperhatikan dan menjaga jarak setidaknya 1-2 meter saat berinteraksi dengan orang lain, terutama dengan seseorang yang sedang sakit atau beresiko tinggi menderita Covid-19. Terdapat beberapa contoh penerapan social distancing yang umum dilakukan, yaitu bekerja dari rumah (work from home), belajar di rumah bagi siswa dan mahasiswa, menunda pertemuan atau acara yang dihadiri banyak orang, tidak mengunjungi orang yang sedang sakit, melainkan cukup melalui panggilan telepon atau telekonferen. Namun sementara pengamat memandang bahwa langkah pencegahan melalui social distancing tidak cukup efektif untuk mencegah perluasan pandemi Covid19, dibuktikan dengan peningkatan pesat pasien positif Covid-19 pada setiap harinya. Tes massal sebagai kebijakan lanjutan juga perlu disertai dengan pertimbangan sosio-ekonomi Indonesia serta kesiapan instrumen kesehatan. Lebih lanjut dinyatakan bahwa kebijakan social distancing yang dipilih pemerintah bukanlah tanpa resiko. kebijakan social distancing dalam jangka panjang dapat memperlambat kegiatan produksi ekonomi (supply shock).

\section{Pengaruh Physical Distancing dan Social Distancing Terhadap Kesehatan}

Persepsi masyarakat Kecamatan Tarogong
Kabupaten Garut pengaruh Physical Distancing dan Social Distancing Terhadap Kesehatan merupakan langkah atau kebijakan yang dilakukan oleh pemerintah untuk membatasi ruang gerak masyarakat dalam melakukan interaksi sosialnya dengan orang lain dengan maksud dan tujuan tertentu dalam hal ini sebagai pencegahan penyebaran infeksi virus Covid-19. Terlebih telah ditemukan pada sejumlah kasus ditemukan pasien yang memiliki imunitas sangat lemah dapat berakibat fatal apabila tidak mendapatkan penanganan medis secara cepat dan tepat yakni dapat mengakibatkan kematian. Virus Covid-19 ini dapat menginfeksi siapa saja dan dimana saja tanpa disadari secara pasti oleh penderitanya, tentunya apabila hal ini tidak segera ditangani atau tidak segera dilakukannya pembatasan sosial dikhawatirkan akan menimbulkan efek domino dimana seseorang akan terus menularkan virus kepada orang lain saat mereka saling berinteraksi. Kebijakan physical distancing dan sosicial distancing yang dilakukkan oleh pemerintah Indonesia merupakan kebijakan yang tepat untuk mengurangi dapak penyebaran infeksi virus Covid-19 di Indonesia. Kebijakan yang dipilihpun telah sesuai dengan himbauan WHO terkait physical distancing dan social distancing.

\section{Dampak Sosial}

Kebijakan PSBB menerapkan pelarangan dan pembatasan semua aktivitas kegiatan sosial maupun budaya yang biasanya dipenuhi kerumunan yang rentan dengan penyebaran COVID-19. Dampak dari keluarnya kebijakan ini pastinya berdampak pada intensitas aktivitas publik di beberapa daerah. Masyarakat di batasi untuk keluar rumah dengan alasan kesehatan ini pasti mambatasi kegiatan sehari-hari masyarakat seperti bekerja, sekolah, kuliah, berdagang dan kegiatan lain yang menghimpun banyak orang di satu tempat. Pembatasan aktivitas kegiatan sosial yang melibatkan beberapa tempat dan fasilitas umum dilakukan dengan cara membatasi jumlah orang dan mengatur jarak interaksi (physical distancing). Tetapi pembatasan ini tidak berlaku pada kegiatan di pusat perbelanjaan pasar, supermarket dan tempat penjualan obat maupun peralatan medis, toko penyedia kebutuhan pokok, bahan bakar seperti SPBU, pelayanan kesehatan dan juga tempat kegiatan olahraga tidak ikut dibatasi secara total. Kemudian, kalau kita update melalui portal berita, akan didapati massifnya phk bagi karyawan/pegawai perusahaan, ini menyusul 
Dampak Ekonomi yang sudah dipaparkan sebelumnya.

Dengan adanya Pemberlakuan social distancing di masa pandemi setidaknya masyarakat dapat mengimplementasikan modal sosial yang meliputi nilai atau norma-norma informal yang dimiliki bersama diantara para anggota suatu kelompok masyarakat yang saling terkait, yang didasarkan pada nilai kepercayaan, norma, dan jaringan sosial dan mereka saling menghargai, pengembangan modal sosial adalah terciptanya kelompok masyarakat yang semakin mandiri, yang mampu berpartisipasi secara lebih berarti.

\section{KESIMPULAN DAN SARAN}

Hasil penelitian dapat disimpulkan bahwa dengan adanya Arief Kresna dan Juni Ahyar setidaknya masyarakat dapat mengimplementasikan Modal Sosial yang meliputi nilai atau norma-norma informal yang dimiliki bersama diantara para anggota suatu kelompok masyarakat yang saling terkait, yang didasarkan pada nilai kepercayaan, norma, dan jaringan sosial dan mereka saling menghargai, pengembangan modal sosial adalah terciptanya kelompok masyarakat yang semakin mandiri, yang mampu berpartisipasi secara lebih berarti. Modal sosial dapat menyelesaikan permasalah warga terutama berkenaan dengan penguatan tali silaturahim, perbaikan dan pemeliharaan sarana pelayanan publik karena memiliki kelebihan dan paling sesuai, meskipun pada komunitas tersebut terdapat modal sosial lain.

\section{REFERENSI}

[1] Arief Kresna dan Juni Ahyar. (2020). Pengaruh Physical Distancing Dan Social Distancing Terhadap Kesehatan Dalam Pendekatan Linguistik.

https://media.neliti.com/media/publications/329 984-pengaruh-physical-distancing-dan-sociald30f26cd.pdf

[2] Endraswara, S. (2006). Metode, Teori, Teknik Penelitian Kebudayaan. Pustaka Widyatama.

[3] Rusydan Fathy. (2019). Modal Sosial: Konsep, Inklusivitas dan Pemberdayaan Masyarakat. https://jurnal.ugm.ac.id/jps/article/download/47 463/pdf

[4] Sakti, F. T., \& Pribadi, G. (2018). Evaluasi Kebijakan Standar Pelayanan Minimal Pelayanan Dasar Pemeliharaan Ketertiban
Umum, Ketentraman Masyarakat dan Perlindungan Masyarakat di Provinsi DKI Jakarta. Jurnal Kelola: Jurnal Ilmu Sosial, 1(2), 98-116.

[5] Setiawan, Y. I. S. (2020). Penetapan Karantina Wilayah Menurut Pandangan Legal Positivisme Dalam Rangka Pencegahan dan Pemberantasan Pandemi Coronavirus Disease (Covid)- 19.

[6] Sugiyono, P. D. (2017). Metode Penelitian Bisnis: Pendekatan Kuantitatif, Kualitatif, Kombinasi, dan R\&D. Penerbit CV. Alfabeta: Bandung.

[7] Suherman A, Mulyana E, Triani W dkk. (2020). Information Literacy Training on the Preparedness of Garut People in Facing Landslide Threats. http://ejournals.fkwu.uniga.ac.id/index.php/IJC E/article/view/157

[8] Suherman A, Tetep , Jamilah, Hermanto, Susanti Y. (2020). Webinars and Workshop on the Utilization of Online Learning Applications during the Covid-19 Pandemic at the MGMP PPKn Garut Regency. https://ejournals.institutpendidikan.ac.id/index. php/PEKEMAS/article/view/41

[9] Suherman A, Widyanti T. Mulyana E. (2020) Nation Character Building for Millennial Generation Based on Local Wisdom of Saminism. https://www.atlantispress.com/proceedings/icssgt-19/125942802

[10] Suherman A,Tetep, dkk.(2020) Webinars and Workshop on the Utilization of Online Learning Applications during the Covid-19 Pandemic at the MGMP PPKn Garut Regency. https://ejournals.institutpendidikan.ac.id/index. php/PEKEMAS/article/view/41

[11] Suherman, Ade (2020).Training Keterampilan Sosial Pada Pembelajaran Ips Berfokus Efikasi Diri Siswa. https://journal.institutpendidikan.ac.id/index.ph p/journalcss/article/view/943

[12] Susanti Y, Patonah R. (2020). Peran Perempuan Terhadap Penguatan Ekonomi Keluarga Di Kabupaten Ciamis. https://jurnal.unigal.ac.id/index.php/edukasi/arti cle/view/4324/0

[13] Tetep, Suherman A. (2020). The Use of Mentimeter Applications in Online Learning during the Covid-19 Pandemic at the MGMP PPKn Garut Regency. 
https://ejournals.institutpendidikan.ac.id/index. php/PEKEMAS/article/view/42

[14] Tetep, Triani W.dkk. (2020). Strengthening Islamic Environmental Awareness through Exploring Poetry as a Learning Resource in Social Studies. http://ejournal.iainbukittinggi.ac.id/index.php/I slam_realitas/article/view/3387

[15] Tetep, Widyanti T. (2019).Eksistensi Ilmu Kanuragan Rajah Pakuwon di Era Globalisasi. https://journal.institutpendidikan.ac.id/index.ph $\mathrm{p} /$ journalcss/article/view/703

[16] Tetep, Widyanti T. (2020). Penggunaan multimedia presentasi powerpoint 2016 untuk meningkatkan hasil belajar pada pembelajaran membaca pemahaman teks prosedur bahasa inggris.

https://journal.institutpendidikan.ac.id/index.ph $\mathrm{p} / \mathrm{tekp} / \mathrm{article} / \mathrm{view} / 810$

[17] Tetep, Widyanti T. (2020). Strengthening Islamic Environmental Awareness through Exploring Poetry As a Learning Resource in Social Studies. http://ejournal.iainbukittinggi.ac.id/index.php/I slam_realitas/article/view/3387

[18] Widyanti T, Tetep, Mulyana E. (2019). Analisis Faktor Pendidikan dan Demografi terhadap Tingkat Literasi Ekonomi Mahasiswa. http://ejournals.fkwu.uniga.ac.id/index.php/BIE $\mathrm{J} /$ article/view/30

[19] Wijiharsono, Erwan Agus Purwanto. 2012. Modal Sosial Sebagai Solusi Mengatasi Permasalahan Masyarakat Studi Kasus Kelompok Jimpitan Pada Lingkungan Rt 70 Dan Rt 71 / Rw 19 Kampung Danunegaran Yogyakarta.

http://etd.repository.ugm.ac.id/home/detail_pen carian/55281

[20] Yuliana, Y. (2020). Corona virus diseases (Covid-19): Sebuah tinjauan literatur. Wellness And Healthy Magazine, 2(1), 187-192.

[21] Yunus, N. R., \& Rezki, A. (2020). Kebijakan Pemberlakuan Lock Down Sebagai Antisipasi Penyebaran Corona Virus Covid-19. Salam: Jurnal Sosial Dan Budaya Syar-I, 7(3).

[22] Yusup, D. K., Badriyah, M., Suyandi, D., \& Asih, V. S. (2020). Pengaruh bencana Covid-19, pembatasan sosial, dan sistem pemasaran online terhadap perubahan perilaku konsumen dalam membeli produk retail. Http://Digilib. Uinsgd. Ac. Id, 1(1), 1-10. 